\title{
Monika Weychert
}

ORCID: 0000-0003-3941-0800

Instytut Badań Przestrzeni Publicznej ASP Warszawa

SWPS Uniwersytet Humanistycznospołeczny

\section{Sztuka artystów wizualnych o romskich korzeniach — od różnicy do równości}

Abstrakt: Artykuł referuje tematy podejmowane przez artystów romskich tworzących prace o Zagładzie Romów wynikające z jej specyfiki: uwidzialnienie miejsc pamięci, wizerunków ofiar, rasowych motywów nazistowskiej zbrodni na Romach. Chciałam prześledzić, jak, kiedy i czy w ogóle owe strategie wpływają na (nie)widzialność romskiej Zagłady wśród narodów większościowych. Zaproponowałam przy tym, aby przyjąć cezurę czasową wyznaczoną przez dwa wydarzenia: zaprezentowanie pawilonu romskiego Paradise Lost na Biennale w Wenecji w 2007 roku i Pierwsze Romskie Biennale zorganizowane w Berlinie w 2018 roku. W tej ramie czasowej analizowałam relacje między narracjami romskiego ruchu politycznego w okresie etnicznej mobilizacji a artystycznymi wypowiedziami artystów romskich. Próbowałam odpowiedzieć na pytania o przyczyny porażki dotychczasowych strategii i obserwowane obecnie, w najnowszych zjawiskach romskiej sztuki współczesnej, poszukiwania dróg wyjścia z impasu. Jedną z nich jest postromskość jako próba redefinicji romskiej tożsamości i spojrzenie na Zagładę Romów z rozszerzonej perspektywy.

Słowa-klucze: Romowie, parias, romska sztuka współczesna, sztuka postromska

Przypominając refleksje Martina Jay’a o trudności z ustaleniem, kiedy właściwie kończy się Holokaust, można postawić tezę, że Zagłada Romów po 1945 roku trwała nadal, ponieważ nie została ani dostrzeżona, ani rozliczona, ani przepracowana - trwała przemoc wobec Romów i trwały ich prześladowania ${ }^{1}$. W czasie wojny Romowie zostali zdziesiątkowani (należy pamiętać, że szacunek utraty 50\% przedwojennej populacji jest jedynie symboliczny i mogło zginąć znacznie więcej osób ${ }^{2}$ ). Tuż po wojnie ocaleni Romowie byli pogrążeni w traumie ${ }^{3}$, ich tra-

${ }^{1}$ Por. M. Jay, Refractions of Violence, New York 2003, s. 58-59.

2 I. Hancock argumentował, że ofiar mogło być więcej — od 1 do 1,5 miliona.

3 Ten aspekt był rzadko omawiany w polu naukowym. Przez lata ukazał się jedynie artykuł: U. Liedtke, P. Peterson, Zur Entschädigung zwangssterilisierter Zigeuner. Sozialpsychologische Einflüsse auf psychische Störungen nationalsozialistisch Verfolgter, „Nervenartzt” 1971, nr 4, s. 197-205. 
dycyjna kultura na skutek wojennych wydarzeń doznała poważnego uszkodzenia ${ }^{4}$, rozbite zostały także wewnętrzne powiązania, rozpadły się przedwojenne więzi łączące Romów z nieromskim światem. János Bársony i Ágnes Daróczi stwierdzają, że „struktura społeczna Romów złamała się [...], a tym samym przez długi czas Romowie nie mieli przywódców, organizacji, sojuszników, reprezentantów politycznych, którzy udokumentowaliby ich straty czy mówili w ich imieniu"5. Nie ulega wątpliwości, że przez społeczeństwa większościowe Romowie zostali zepchnięci w okresie powojennym na dziesięciolecia w całkowitą niewidzialność jako pariasi: jako nieobywatele czy obywatele drugiej kategorii nie mieli możliwości, by w jakikolwiek sposób działać politycznie, publicznie czy społecznie (na przykład utrudnienia w stowarzyszaniu się); jako „ludzie zbędni” poddawani byli prewencji i dalszym represjom, $\mathrm{w}$ tym po prostu usuwani z pola widzenia: więzieni, odseparowywani w gettach, zakładach reedukacyjnych, ośrodkach dla osób upośledzonych; uznani za lud bez historii zostali wykluczeni ze wspólnoty pamięci i wspólnoty żałoby po ofiarach nazizmu.

Dla politycznego ruchu romskiego, który miał zmienić tę sytuację, przełomowe znaczenie miał zorganizowany przez francuski Comité International Tsigane wspólnie z brytyjskim Gypsy Council Pierwszy Światowy Kongres Romów w Orpington niedaleko Londynu w dniach 1-12 kwietnia 1971 roku. Powołano wtedy do życia International Gypsy Committee (Międzynarodowy Komitet Cyganów) - przemianowany na kongresie w 1977 roku na International Romani Union - IRU (Międzynarodową Unię Romów), organizację reprezentującą Romów przed innymi organizacjami, państwami oraz ONZ. Zaproponowano wówczas społeczeństwom większościowym wizję narodu romskiego o specyficznym statusie: będącego $\mathrm{w}$ diasporze i pozbawionego roszczeń terytorialnych — „naród bez państwa”, ,społeczność nieterytorialną”, „mniejszość europejską” czy też „nieterytorialną grupę etniczno-narodową"6. Ustalono także wygląd flagi romskiej oraz hymn. $Z$ pewnością panromski ruch polityczny był bardzo interesującym przykładem tworzenia tożsamości-projektu ${ }^{7}$. Dzisiaj z perspektywy czasu

${ }^{4}$ H. Krokowski, Die Last der Vergangenheit. Auswirkungen nationalsozialistischer Verfolgung auf deutsche Sinti, Frankfurt am Main 2001, s. 52-53.

5 J. Barsony, A. Daróczi, Pharrajimos: The Fate of the Roma During the Holocaust, Amsterdam-New York-Brussels 2008, s. 8; S. Kapralski, Naród z popiołów. Pamięć zagłady a tożsamość Romów, Warszawa 2012, s. 152.

${ }^{6}$ Por. S. Kapralski, op. cit., s. 409.

${ }^{7}$ Konstruowanie tożsamości wykorzystuje jako budulec materiały pochodzące z historii, geografii, biologii, z instytucji produkcji i reprodukcji, z pamięci zbiorowej i osobistych marzeń, z aparatów władzy i objawień religijnych. Jednak materiały te są przetwarzane przez jednostki, grupy społeczne i społeczeństwa. Castells wyróżnia trzy formy i źródła budowania tożsamości: tożsamość legitymizującą — narzucaną przez instytucje społeczne w celu rozszerzenia i zracjonalizowania ich dominacji wobec aktorów społecznych; tożsamość oporu — konstruowaną przez tych aktorów, którzy znajdują się w gorszym położeniu, w warunkach dewaluacji lub stygmatyzacji przez logikę dominacji, tożsamość jest konstruowana na zasadach przeciwstawienia się zasadom, jakim hołdują 
można jednak uznać, że stworzenie quasi-narodowej konstrukcji, jaką była zaprojektowana wspólna tożsamość, będąca kliszą czy trawestacją organizmu narodowego i towarzyszącej mu symboliki, osłabiło polityczną sprawczość ruchu. Nie uwzględniało też paneuropejskiej specyfiki, z którą europejskie społeczeństwa powinny się zmierzyć, wypracowując zupełnie nowe narzędzia dialogu z „,nieterytorialną mniejszością". W gruncie rzeczy potwierdzała ona europejską wizję podmiotowości, do której Romowie powinni się dopasować, by zostać zauważeni. Wskazuje na to na przykład Paloma Gay y Blasco, która pisze, że Romowie „przeredagowują treść tożsamości zgodnie z niecygańskimi wartościami i modelami kulturowymi"

Przypomnieć tu należy, że Romowie to zatomizowane grupy, których kultura kształtowała się równolegle $\mathrm{w}$ wielu różnych kontekstach historycznych, politycznych, religijnych. Dotąd wspólny mianownik tworzyły jedynie kształtowane z zewnątrz wizerunki i stereotypy. Forma samoorganizacji jako quasi-narodowej formacji sprawiła, że Romowie sami naturalizowali taki stereotypowy obraz. Projekt aktywistów i intelektualistów romskich miał doprowadzić do uśrednienia i pogodzenia roszczeń wielu grup mieszkających w różnych państwach narodowych, nie uwzględniając kontekstów lokalnych. Pomijał też inne kwestie wewnętrzne: sytuację romskich kobiet, problemy osób nieheteronormatywnych, zróżnicowanie klasowe, tożsamości halfie. To w późniejszym okresie doprowadziło do rozłamu wśród aktywistów, konkurencyjności różnych związków i stowarzyszeń aktywistów romskich bądź uniewidzialnienia wewnętrznie sprzecznych interesów różnych grup.

Narracje sztuki wpisywały się jednak w taką właśnie panromską wizję tożsamości. Tímei Junghaus zawdzięczamy pierwszą i nadal pozostającą bez znaczącej konkurencji definicję pojęcia „współczesna sztuka romska”. Termin ten jest nieprecyzyjny i umowny - Tímea Junghaus unika kodyfikacji i tworzenia wyznaczników estetycznych. Porównuje ten rodzaj sztuki między innymi do fizycznych właściwości czarnej dziury:

Czarna dziura nie istnieje, nie ma treści, ale zasysa i pochłania wszystko, co napotyka. W ten sposób pokazuję, jak romska sztuka może funkcjonować i jak powinno się ją postrzegać. Być może tak naprawdę nie ma czegoś takiego jak romska sztuka, ponieważ romska sztuka może istnieć tylko do momentu, kiedy Romowie osiągną równość i wolność. Ten moment jest jednocześnie blisko i daleko, nie wiemy, kiedy nastąpi, ale też nie możemy sobie tego wyobrazić. I do tego czasu termin „współczesna sztuka romska” jest najlepszym określeniem tego aspektu społeczności romskich i romskiej tożsamości ${ }^{9}$.

instytucje społeczne; tożsamość projektu — ma miejsce wtedy, gdy aktorzy społeczni na podstawie dostępnych materiałów kulturowych budują nową tożsamość, która redefiniuje ich pozycję w społeczeństwie, tym samym dążą do transformacji całej struktury społecznej. Zob. idem, Siła tożsamości, przeł. S. Szymański, Warszawa 2008, s. 23.

8 P. Gay y Blasco, Gypsy/Roma diasporas. A comparative perspective, „Social Anthropology” 10, 2002, nr 2, s. 186; jeśli nie podano inaczej, przeł. M.W.

9 T. Junghaus - wywiad własny, niepublikowany; zob. S. Kapralski, M. Kołaczek, J. Talewicz-Kwiatkowska, Kierunek: przyszłość. 25 lat wolności a Romowie, Kraków 2015, s. 167. 
Pojęcie romska sztuka współczesna to jedno z największych osiągnięć romskiego ruchu emancypacyjnego zapoczątkowanego w Europie pod koniec lat sześćdziesiątych XX wieku ${ }^{10}$.

W określeniu „współczesna sztuka romska” wszystkie słowa są znaczące. Sztuka ta jest współczesna, ponieważ odbiega od wizji sztuki romskiej jako folklorystycznego reliktu przeszłości. Jest sztuką, choć niejednokrotnie podważano jej status (widząc w niej twórczość naiwną lub rzemiosło) i przede wszystkim sztuka ta jest romska. Chociaż w sztuce współczesnej narodowe etykietowanie zasadniczo nie ma dziś znaczenia - takie określenia jak współczesna sztuka polska, francuska, rumuńska czy łotewska nie są znaczące, a wyłącznie przymiotnikowe — to „sztuka romska” stanowi nurt w sztuce ściśle powiązany z szerszym tłem kulturowym, poruszający problem funkcjonowania Romów w sferze zarówno sztuki, jak i całej kultury i społeczeństwa, a także zmierzający do wypracowania języka w sztuce, który te kwestie uwidzialni (podobnie jak w wypadku innych rodzajów sztuki emancypacyjnej, na przykład sztuki Afroamerykanów, sztuki feministycznej czy gejowskiej).

Przykładem może być tu kolażowa seria Mariki Schmiedt ${ }^{11}$ z 2012 roku. Artystka wprost zestawiła obrazy Zagłady Romów z obrazami dzisiejszych prześladowań, a skrót EU oraz unijną flagę — ze swastyką. Do tego dodała podpisy, które nie pozostawiają żadnej wątpliwości i pola do złożonych interpretacji. Między innymi zestawiła zdjęcia $\mathrm{z}$ wywózki do obozu koncentracyjnego w nazistowskich Niemczech (Asperg, 1940) ze zdjęciem deportacji Romów rumuńskich z Francji (Lille, 2012). Pomiędzy nimi umieściła flagę europejską z dopiskiem: repeat order. Zgodnie ze słownikowym znaczeniem owo „powtarzające się zamówienie” znamionuje "uznanie stałych klientów' i "należyty zwrot z inwestycji' ${ }^{12}$. Schmiedt wskazała tu ciągłość antyromskiej polityki François Hollande'a i jego poprzednika, Nicolasa Sarkozy'ego. W pracy Stop Bio Knoblauch Romanes (2012) Marika Schmiedt podniosła też kwestię tak zwanego przemysłu romskiego, czyli klęskę programu unijnego „Dekada integracji Romów 2005-2015”, który opierał się na rasistowskiej retoryce „cywilizowania Romów” i którego beneficjentami byli na przykład przedsiębiorcy, a nie społeczność romska. Artystka wskazuje też, że oczywista analogia losu Romów obecnie i podczas II wojny światowej jest nadal nierozpoznana i niewidzialna; choć na poziomie wizualnym wydaje się oczywista — podobnie jak niewidzialne były i nadal są same cierpienia Romów.

10 T. Junghaus, Romska sztuka wspótczesna - rewolta podporządkowanych, przeł. I. Suchan, [w:] Romano kher. O romskiej sztuce, tradycji i doświadczeniu, red. M. Weychert Waluszko, Warszawa 2013, s. 39-40.

11 Marika Schmiedt urodziła się w 1966 roku w Traun, w Górnej Austrii. Aktorka, reżyserka i artystka wizualna. Od 1999 roku do chwili obecnej prowadzi badania osób, które przeżyły lub były świadkami prześladowań Romów i Sinti od Zagłady Romów do dzisiaj. Wykładowczyni akademicka. Blog artystki: http://marikaschmiedt.wordpress.com/.

12 Repeat order, [hasło w:] Cambridge English Dictionary, https://dictionary.cambridge.org/pl/ dictionary/english/repeat-order (dostęp: 9.09.2019). 
Spośród jej kilkunastu prac dotyczących konkretnych wydarzeń z całej Europy: Węgier, Macedonii, Słowacji itd., zestawionych z obrazami Zagłady Romów, ta najbardziej abstrakcyjna przedstawia polowanie. Jest to praca Homage to Frida Kahlo “The Little Deer" 1946 (2012), czyli reprodukcja jednego z bardziej znanych obrazów Kahlo w zmienionej tonacji: ciało jelenia przeszytego grotami strzał łowcy tym razem przedstawione zostało w odcieniach czerwieni. W oryginale malarka zaprezentowała siebie jako hybrydę człowieka-zwierzęcia i kobiety-mężczyzny wystawionej na wieczne cierpienie: zranienia, z których łowca czerpie satysfakcję; niczym w portretach Świętego Sebastiana. Jednak tam, gdzie znajduje się twarz czujnej i nieodczuwającej bólu poranionego ciała Fridy Kahlo, w grafice Schmidt umieszczone zostało koło Dharmy. Napis nad reprodukcją głosi: „Roma in EU-rope” [Romowie w EU-ropie].

Zagłada ujmowana jest $\mathrm{w}$ wypadku tych prac jedynie jako element przemocy kolonialnej, przemocy antycyganizmu jako zjawiska „długiego trwania”:

Tradycja ta ma [...] ogromny ładunek emocjonalny i jest w stanie uprawomocnić emancypację Romów w kategoriach moralnych jako rekompensatę za prześladowania w przeszłości i obronę przed nimi na przyszłość. Centrum tej wizji stanowi doświadczenie zagłady w czasie II wojny światowej. Powiązanie tej wizji z „nurtem nacjonalistycznym” [Romów jako jednego paneuropejskiego narodu - M.W.] i ,indyjskim” [w sensie „wynalezionej tradycji” wspólnego pochodzenia z Indii — M.W.] może zniwelować znaczenie słabszych punktów prześladowania: syndromu mentalności ofiary, ahistoryzmu i zależności od zewnętrznego, nieromskiego układu odniesienia. Mogą one być zrównoważone przez nacisk na romski opór, umiejętność samoorganizacji i przetrwania w najróżniejszym otoczeniu, a także przez własną perspektywę historyczną romskich ruchów politycznych. A zatem kombinacja politycznego nacjonalizmu z nurtem prześladowań kulminujących w czasie Holokaustu może stworzyć nie tylko mocną „tożsamość obronną”, wskazującą na niegodziwość i zarazem nieskuteczność antyromskich prześladowań, lecz także skuteczny dyskurs retoryczny i jednocześnie — przypuszczalnie — stać się szerzej akceptowanym dyskursem popularnym

- pisze Kapralski ${ }^{13}$.

Warto zatem pochylić się nad tym sposobem ujmowania antycyganizmu jako niewyczerpującego się modelu relacji Romów z nieromskim światem. Doświadczenie bycia „zwierzyną łowną” dla nacjonalistycznych bojówek spaja wszystkie grupy i wobec niego lokalne różnice schodzą na dalszy plan. Symptomy scenariusza przeszłej przyszłości stają się bowiem teraźniejszym wyzwaniem dla wszystkich Romów w Europie i panromską ideologią polityczną. Wizerunek romskiej ofiary pozostaje niezmienny. Taka „tożsamość obronna” wiąże się z pewnym paradoksem. Mianowicie naturalizuje i uwidzialnia jedynie różnicę między „nimi” a „nami”, która mimo że w tym wariancie jest afirmowana, to jednak jedynie jako „punkt widzenia uogólnionego innego”, i wciąż oddala owego innego od równości $^{14}$. Jak pisze Terry Eagleton:

13 S. Kapralski, op. cit., s. 303.

14 Por. S. Benhabib, Prawa Innych. Przybysze, rezydenci i obywatele, przeł. M. Filipczuk, Warszawa 2015. 
Jak każdy ruch radykalny polityka tożsamościowa jest wewnętrznie sprzeczna: jesteś wolny, gdy nie musisz się już przejmować, kim właściwie jesteś. W tym sensie cel kłóci się ze środkami. [...] Każda realna afirmacja różnicy ma zatem wymiar uniwersalny ${ }^{15}$.

Paradoksem współczesnej sztuki romskiej jest zatem to, że jest ona niekiedy radykalna, transgresyjna, krytyczna i aktywistyczna, a jednocześnie wspiera niejednokrotnie w swoich narracjach (prezentowanych przez artystów, lecz także kuratorów) „tożsamość obronną” oraz modernistyczny model narodowy oparty na etnicznej różnicy, który ma ująć w karby transnarodową i hybrydyczną społeczność Romów na świecie. Być może w tym należy upatrywać jej nieskuteczności w uwidzialnianiu istotnych przecież problemów, z którymi Romowie się mierzą, i ich losów w perspektywie historycznej.

W początkach kwietnia 2018 roku w Berlinie odbyło się „Come Out Now!” — pierwsze w pełni romskie biennale. Podczas biennale pojawiły się wątki, które już wcześniej wybrzmiewały we współczesnej sztuce romskiej: krytyka kartografii od-dzielenia, krytyka historiografii nieuwidzialniającej historię Romów, figura walecznego pariasa-buntownika, pariasa-rebelianta, perturbacje związane ze strategią uchodzenia oraz problem urasowienia stosunków z Romami. Jednak artystyczne, antyesencjonalistyczne i antynormatywne z definicji strategie romofuturyzmu i queerowania romskości znacząco przewartościowały refleksję na temat tego, czym jest polityczna wspólnota Romów i polityczna sprawczość.

Zaprezentowane wtedy performansy ujmowały historię Romów-pariasów jako wynik spotkania z radykalnym obcym, obcym z innej planety. Tym samym przeciwstawiając się uwewnętrznianiu figury ofiary oraz humanistycznemu i historycznemu uchwyceniu. Jak pisze Mbembe, jeśli pariasa sprowadzono niegdyś do roli przedmiotu i narzędzia, to

W gruncie rzeczy Ziemia w swojej historycznej konfiguracji nie byłaby niczym innym jak rozległym więzieniem dla tego człowieka-metalu, człowieka-srebra, człowieka-drewna i człowieka-płynu poddawanego nieskończonym przeobrażeniom. Mieszkaniem dla tego metamorficznego, a zarazem plastycznego naczynia, byłby w ostateczności cały Wszechświat. Kondycję ziemską zastąpiłaby tym samym kondycja kosmiczna, w której to, co ludzkie, pogodziłoby się z tym, co zwierzęce, roślinne, mineralne, ze wszystkimi innymi żywymi siłami, czy to solarny$\mathrm{mi}$, czy nocnymi lub astralnymi ${ }^{16}$.

Dom Alchemycal Sisters (Mihaela Drăgan, Riah Knight, Mefisto von Bedre ${ }^{17}$ ) przedstawiał Romki jako cybernetyczną sektę czarownic, której wiedza jest wie-

15 T. Eagleton, Po co nam kultura?, przeł. A. Górny, Warszawa 2012, s. 95.

16 A. Mbembe, Polityka wrogości. Nekropolityka, przeł. U. Kropiwiec, K. Bojarska, Kraków 2018, s. 175-177.

17 Mihails Kokarevics, znany także jako Mefisto von Bedre, urodzony w 1986 roku na Łotwie, obecnie mieszka i pracuje w Peterborough; jest fotografem, rysownikiem, malarzem i performerem; jego dzieła dotyczą idei autoprezentacji. Mihaela Drăgan urodziła się w 1986 roku w Rumunii; obecnie mieszka i pracuje w Bukareszcie i Berlinie; jest aktorką i dramatopisarką. W 2014 roku założyła „teatr rewolucyjny” Giuvlipen Theatre Company we współpracy z innymi romski- 
dzą alternatywną i niedocenioną na naszej planecie. Wystąpienie Franciski Far$\operatorname{kas}^{18}$ było z kolei fantazją na temat obcej żyjącej w ciele Romki ${ }^{19}$. Dla tych manifestacji romofuturyzmu niewątpliwą inspiracją był afrofuturyzm. Ponieważ jak dotąd nie powstały żadne teksty dotyczące samego romofuturyzmu, warto w tym miejscu krótko się odnieść do afrofuturyzmu jako teoretycznej ramy pozwalającej zinterpretować owe performansy. Afrofuturyzm jest także reakcją na poczucie braku w historii, niemniej odrzucenie reguł „tożsamości obronnej” zbudowanej na figurze ofiary pozwala $w$ jego ramach na inkorporowanie scenariuszy alternatywnych, także pozytywnych, i uchwycenie procesów dziejowych w zupełnie nowych kategoriach. Jak pisze Dariusz Brzostek:

W tym sensie afrofuturyzm tworzy nieobecne dotąd w (pop)kulturze alternatywne modele narracji tożsamościowych, uwzględniających takie kategorie, jak rasa czy różnica — [jednak] poddane uprzednio reinterpretacji i przewartościowaniu (a zatem pozbawia je wymiarów stygmatyzującego piętna, brzemienia okcydentalizmu czy protekcjonalnego eurocentryzmu) i buduje w postaci tekstów literackich, filmowych, muzycznych, swoiste „,wehikuły fantazjowania”, pozwalające tym członkom społeczności, którzy dotąd znajdowali się na marginesie głównego nurtu produkcji kulturowej, odnaleźć swoje miejsce w popkulturowym imaginarium. A przy okazji afrofuturyzm staje się także narracją, w ramach której dokonuje się reinterpretacja

mi aktorkami. Giuvlipen ma feministyczny program i porusza kwestie wczesnego małżeństwa, antyfaszyzmu, mowy nienawiści, hiperseksualizacji romskich kobiet. W 2015 roku zagrała w filmie fabularnym Aferim!, opowiadającym o zbiegłym romskim niewolniku, w reżyserii Radu Jude (nagrodzony Srebrnym Niedźwiedziem na Międzynarodowym Festiwalu Filmowym w Berlinie). Pracuje w Berlinie w teatrze Maxim Gorki. Jest także reżyserką Teatru Uciśnionych, gdzie pracuje z kobietami romskimi. Była jedną z sześciu finalistek konkursu Gilder/Coigney International Theatre Award w Nowym Jorku w 2017 roku, który docenia wyjątkową pracę kobiet teatru z całego świata. Zob. reportaż na jej temat: Mihaela Dragan: A weird Roma feminist, https://www. youtube.com/watch? $\mathrm{v}=\mathrm{s} 768 \_1 j \mathrm{juUg}$ (dostęp: 20.09.2019); wywiad: https://www.youtube.com/ watch?v=6XXa5-rRgGk (dostęp: 20.09.2019). Riah May Knight urodziła się w 1996 roku w Brighton, w wielkiej Brytanii; jej matka Patricia Knight była działaczką romskiego ruchu na rzecz praw obywatelskich, dlatego Riah May Knight od najmłodszych lat była zaangażowana politycznie i społecznie. Szkołę ukończyła z wyróżnieniem. Przebywała na rezydencji w prestiżowym londyńskim Roundhouse. Jest muzyczką i piosenkarką; obecnie pracuje nad debiutancką płytą. Ma stałą audycję FUSE w radiu Platform B. Zob. Interview with "Roma Armee” star Riah Knight, https://www.youtube.com/watch?v=HBoCx2pyt0w (dostęp. 20.09.2019).

18 Franciska Farkas urodziła się w 1984 roku w Gyöngyös na Węgrzech. Jej rodzice złożyli wniosek o rozwód, gdy miała 13 lat, zmuszając ją do pracy i pomagania matce; pracowała jako modelka, gospodyni w hotelu, kelnerka, barmanka, pracownica socjalna. Szkołę nauczania dramatu ukończyła dopiero w 2017 roku; jest aktorką i nauczycielką dramatu. Jest jedną z niewielu aktorek na Węgrzech, które otwarcie przyznają się do romskich korzeni. Zagrała główną rolę w szwajcarskim filmie Viktoria - A Tale of Grace and Greed (2013) i jako aktorka drugoplanowa w Golden Life, serialu HBO (2016-2017) i wielu filmach węgierskich. Gra na scenach teatralnych i reżyseruje. Została nagrodzona: jako najlepsza aktorka na 14. Węgierskim Festiwalu Filmowym w Los Angeles (2014), jako Najlepsza Aktorka w 48-godzinnym Projekcie Filmowym (2015), jako najlepsza aktorka drugoplanowa węgierskich profesjonalistów telewizyjnych (2016).

19 Por. R. Księżyk, Afrofuturystki: różnica i przemiana, „Pismo” 5.06.2018, https://magazynpismo.pl/afrofuturystki-roznica-i-przemiana/\# (dostęp: 9.09.2019). 
historii, uwzględniająca i te wydarzenia oraz procesy, do których w rzeczywistości dojść nie mogło, np. z powodu polityki kolonialnej $[\ldots]^{20}$.

Twardy panromski konstrukt tożsamościowy, tworzony dotychczas przez romski ruch polityczny, artyści podczas biennale naruszyli, nie tylko sięgając po narzędzia afrofuturyzmu, lecz także otwarcie korzystając ze strategii queerowania romskości. Jak bowiem pisze Spivak,

esencjonalizm jest jak dynamit lub silny narkotyk: stosowany rozsądnie może być skuteczny w likwidowaniu niepożądanych struktur lub łagodzeniu cierpienia; użyty jednak w sposób niekrytyczny staje się destruktywny i uzależniający ${ }^{21}$.

\section{W podobnym duchu Joanna Bednarek zauważa z kolei, że}

teoria queer może przyczynić się do stworzenia takiego porządku politycznego, w którym żadne cechy nie będą przeszkodą dla uczestnictwa, a kształt sfery publicznej określany będzie przez interakcje znajdujących się w niej ciał; porządek umożliwiający politykę, w obrębie której „ciała wchodzą ze sobą w relacje, których nie da się określić z góry"22.

Manifestacją takiego właśnie sposobu politycznego mówienia o problemach mniejszości był spektakl Roma Armee, zainicjowany przez siostry Simonidę Selimović ${ }^{23}$ i Sandrę Selimović ${ }^{24}$, w reżyserii Yael Ronenem.

Na scenie występują Romki/Romowie i travellersi z Austrii, Serbii, Niemiec, Kosowa, Rumunii, Anglii i Szwecji. Dzięki wspólnemu procesowi badawczemu poddają analizie osobiste doświadczenia, historyczne uwarunkowania i współczesne incydenty antycyganizmu. Aktorami są również osoby o izraelsko-niemiecko-turecko-berlińskiej tożsamości: armia romska ma charakter

20 D. Brzostek, Black Science — Black Magic. Czy afrofuturyzm jest narracja poznawcza?, http://www.journal.doc.art.pl/pdf14/artbasedresearch_brzostek_art_and_documentation14.pdf (dostęp: 10.09.2019).

21 G. Chakravorty Spivak, Krytyka postkolonialnego rozumu. W stronę historii zanikajacej wspótczesności, [w:] Teorie literatury XX wieku. Antologia, red. A. Burzyńska, M.P. Markowski, Kraków 2006, s. 651.

22 J. Bednarek, Queer jako krytyka społeczna, Biblioteka Online Think Tanku Feministycznego 2014, s. 24, http://www.ekologiasztuka.pl/pdf/f0132_bednarek_queer_krytyka_spoleczna.pdf (dostęp: 6.08.2019).

23 Simonida Selimović urodziła się w Serbii w 1979 roku. Jako dziecko wyemigrowała z rodziną do Austrii. Karierę rozpoczęła jako aktorka dziecięca — grała w serialu dla dzieci Operacja Dunarea, w filmie Ciao Cherie Niny Kusturicy. Na scenie teatralnej w Wiedniu często współpracuje z Tiną Leisch i Sandrą Selimović. W 2010 roku wraz z siostrą założyły Romano Svato, pierwsze feministyczne i profesjonalne stowarzyszenie — romski teatr w Wiedniu, a także Mindj Panther, gdzie działa jako feministyczna raperka i działaczka przeciwko rasizmowi oraz na rzecz równości Romów.

${ }^{24}$ Sandra Selimović urodziła się w 1981 roku w Serbii. W wieku 5 lat wyemigrowała z rodziną z Serbii do Wiednia. Jest aktorką, reżyserką i piosenkarką. Karierę sceniczną rozpoczęła w 1994 roku i stała się popularną aktorką, reżyserką i raperką na niezależnej scenie teatralnej w Wiedniu. Występuje głównie w teatrze młodzieżowym Dschungel Wien i Theater des Augenblicks. Jako wzór asertywnej i pewnej siebie Romni jest orędowniczką wzmocnienia pozycji kobiet w społeczności romskiej, a także angażuje się w walkę z niechęcią wobec Romów i dyskryminacją. W 2010 roku wraz ze swoją siostrą Simonidą Selimović założyła Romano Svato. 
ponadnarodowy, zróżnicowany, feministyczny, queer. W czasach gdy Europa jest zagrożona dryfowaniem w neofaszyzm, grupa aktorów wzywa armię romską do samoobrony. Armia ma walczyć z dyskryminacją strukturalną, homofobią, rasizmem i antycyganizmem. Ale także poddaje krytyce zinternalizowaną rolę ofiary wiecznej przemocy ${ }^{25}$.

Roma Armee balansuje na pograniczu teatru dokumentalnego i mockumentu. Aktorzy-postacie przeprowadzają swoistą pracę autoetnograficzną — dzielą się z publicznością własnymi biografiami, zaprawiając je kampowym humorem i ironią. Jak refren powtarzają się sceny, w których postacie opowiadają o sobie, przedstawiają się kolejno — za każdym razem odnosząc się do innej kategorii lub roli społecznej. Pokazują, że tożsamość to narastająca w toku doświadczeń zdolność do integrowania wszystkich identyfikacji obejmujących zmienny bieg libido, umiejętności oraz możliwości wynikłych z ról społecznych, a „romskość” jest zaledwie jednym $\mathrm{z}$ wielu czynników, które wpływają na to, kim dane osoby są same dla siebie i kim stają się dla innych. Ta subiektywizacja rozsadza deklaratywną wspólnotę rozumianą jako „punkt widzenia uogólnionego innego”. Postacie Roma Armee, a jednocześnie aktorzy — Mehmet Ateşçi (z pochodzenia Turek), Hamze Bytyci, Mihaela Drăgan, Riah May Knight, Lindy Larsson ${ }^{26}$, Orit Nahmias (z pochodzenia Żydówka), siostry Selimović - tworzą swoje wizytówki: skąd pochodzą, jaką mają orientację seksualną, co w życiu robią i co lubią. Różnice między tymi osobami są bardziej znaczące niż podobieństwa, choć wspólnie tworzą „romską armię”, a dla odmiany sieć podobieństw między nimi nie opiera się wcale na etniczności.

W trakcie spektaklu Roma Armee Lindy Larsson czy Sandra Selimović otwarcie mówią o swojej nieheteronormatywności. Selimović ze sceny zadała retoryczne pytanie o to, czemu mówi o swojej orientacji, skoro tematyka Roma Armee miała być romska. Dumnie ogłasza, że jest Romką i jest queer, i nie ma zamiaru za to przepraszać. Jak zauważa Arman Heljic, performatywny akt mowy - publiczny coming out Sandry Selimović - jest kluczem do narracji Roma Armee. Bohaterka jest bowiem w każdym środowisku narażona na upraszczającą stereotypizację: jako lesbijka przez Romów może nie być uznawana za właściwą reprezentantkę Romów, przez białych może być uznawana jedynie za uciśnioną ofiarę swego środowiska, przez lesbijki zaś traktowana jest jako femme orienta-

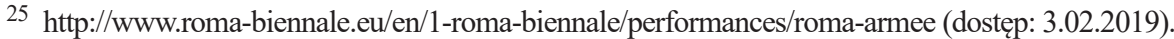

26 Lindy Larsson urodził się 1974 roku w Ljuder w Szwecji. Studiował na University College of Acting w Sztokholmie. Pracuje w Szwecji w takich teatrach, jak The Royal Dramatic Theatre, Malmö Opera, Stockholm City Theatre, Malmö City Theatre i Uppsala City Theatre; jest także piosenkarzem w orkiestrze Lindy \& Bon Bon Band. W 2010 roku otrzymał nagrodę Thalia (Kvällsposten) za rolę w interpretacji Carmen w teatrze miejskim Malmö w reżyserii Kajsy Giertz, a w 2011 roku Nagrodę Såstaholms Film and Stage Art (z zespołem). Film inspirowany biografią Larssona: Lindy: the Return of Little Light, reż. Ida Persson Lännerberg, Sweden 2019. 
$l e^{27}$. Dumnie ogłaszając ze sceny, że tylko jako Romka i jako lesbijka może być spójna tożsamościowo i że tylko w ten sposób znajduje samoakceptację, przecina wszelkie możliwości zaatakowania jej „słabego” punktu. Selimović daje też świadectwo przemian obyczajowych w środowisku romskim, opowiadając o swojej relacji z ojcem tradycjonalistą: „Dawno nie pyta mnie o to, czy wyjdę za mąż. Teraz już nawet nie pyta, czy będę miała żonę".

W mającym premierę rok później filmie dokumentalnym Lindy: the Return of Little Light widzimy scenę, kiedy Lindy Larsson robi rozgrzewkę i przygotowuje się do premiery Roma Armee — jest zadowolony, że wypowie na głos swoją historię, lecz — inaczej niż Selimović - jest jednocześnie przerażony, że zrani swoją rodzinę $e^{28}$. Orientacja homoseksualna jest bowiem przez romskie społeczności tabuizowana od stuleci. W pełnym świetle problem ten postawiła dopiero przełomowa książka Cygański chłopiec. Byłem obcy wśród swoich Mikey’a Walsha, wydana w 2009 roku $^{29}$. Opowieść o molestowanym przez wuja chłopcu, którego ojciec wychowuje na boksera macho, pokazuje, czym się kończy konieczność ukrywania orientacji i jakie może mieć reperkusje.

Choć tej demonstracji sztuki postromskiej nie towarzyszy jeszcze refleksja teoretyczna, warto raz jeszcze przywołać stwierdzenie Wojciecha Szymańskiego, który antycypował kilka lat temu trafnie to, co wydarzyło się w Berlinie podczas romskiego biennale:

Sztuka tworzona w takim paradygmacie zachowywałaby swój romski rodowód, jednocześnie go znosząc. Wymykając się prawu wyłączonego środka, byłaby sztuką romską, jednocześnie nią nie będąc. Korzystałaby z transnarodowych cech romskości, rezygnując jednak z niebezpieczeństw płynących ze zbyt wąskiego rozumienia etniczności. Stałaby tym samym na pozycjach słabej i rozmytej tożsamości, unikającej dookreśleń i dopowiedzeń ${ }^{30}$.

Wydaje się, że romski ruch polityczny dał się uwieść iluzji fantazmatu wspólnoty, który sam wytworzył. Jednak wspólnota mniejszości pod pewnymi względami jest funkcją dominacji, opresji, regulacji i dyscypliny — jak pisze Iris Marion Young:

Ideał wspólnoty stawia jedność ponad różnicę, bezpośredniość ponad mediację, współodczuwanie ponad uznanie ograniczeń własnego rozumienia innych z ich punktu widzenia. Wspólnota jest zrozumiałym marzeniem, wyrażającym pragnienie transparentnych dla siebie nawzajem jaźni, związków opartych na wzajemnej identyfikacji, społecznej bliskości i komforcie. Marzenie to jest zrozumiałe, ale politycznie problematyczne, gdyż ludzie nim motywowani będą pró-

27 A. Heljic, The Revolution is Here and Now. The Revolution is Roma, Queer, and Feminist, HowlRound, https://howlround.com/revolution-here-and-now (dostęp: 8.08.2019).

28 Lindy: the Return of Little Light...

29 M. Walsh, Cygański chłopiec. Byłem obcy wśród swoich, przeł. T. Tomczyńska, Warszawa 2011. Choć pod pseudonimem, Mikey Walsh jest aktywistą ruchu LBGT. Znamy jego wizerunek — na przykład wypowiedź o doświadczeniu coming outu: https://www.youtube.com/watch?v=gvwtJjGrlus (dostęp: 16.10.2017).

30 W. Szymański, Od cyganerii do sztuki post-romskiej i z powrotem, „Studia Romologica” 2016, nr 9, s. 34. 
bować thumić występujące pomiędzy nimi różnice lub domyślnie wykluczać ze swoich grup politycznych osoby, z którymi się nie identyfikują [...]. Ideał wspólnoty totalizuje i pozbawia wymiaru czasowego własną koncepcję życia społecznego poprzez ustanawianie opozycji między autentycznymi i nieautentycznymi relacjami społecznymi. Wymiaru czasowego pozbawione jest również jego rozumienie zmiany społecznej, pożądane społeczeństwo stanowi bowiem całkowitą negację tego, które istnieje obecnie. Ideał wspólnoty uniemożliwia zatem uchwycenie przejścia od tego, co zastane, do tego, co ma być, a co byłoby zakorzenione w zrozumieniu sprzeczności i możliwości istniejącego społeczeństwa ${ }^{31}$.

„Rozszczelnienie” unifikującego i totalizującego projektu tożsamościowego podczas biennale sprawiło, że można było tam swobodnie mówić o wszystkim tym, co dotąd było wypierane, na przykład o tym, że polityczną sprawczość ogranicza nie tylko większościowa rama, lecz także wewnętrzne konflikty, lub o tym, jak trudno zmieścić się w wyidealizowanym wspólnym mianowniku wykreowanej politycznie w latach siedemdziesiątych tożsamości legitymizacyjnej, a przede wszystkim o tym, jak tej narzuconej subalternom w ramach konsensualnej widzialności ramie reprezentacji można i trzeba się przeciwstawić.

„Come Out Now!” Pierwsze Romskie Biennale pokazywało, że „my” nigdy nie jest trwałą konstrukcją i trzeba każdorazowo „nas” wytwarzać w drodze negocjacji. Podczas biennale rzucono zatem światło na to, co było dotąd niewidzialne w reprezentacji Romów, pokazując, że wspólnota nie jest tym samym co legitymizacyjna tożsamość kolektywna. Kiedy bowiem diaspora kwestionuje pojęcie tożsamości i uruchamia dynamiczny proces jej formowania na nowo, ujawnia moc, jaką mają ludzie, by tworzyć samych siebie ${ }^{32}$. W tym sensie romska raperka o płynnej seksualności może/powinna być tak samo uprawniona do reprezentacji politycznej Romów jak starszy romski heteroseksualny lider-aktywista i oboje mogą/powinni mieć taką samą sprawczość w decyzjach dotyczących wspólnoty romskiej. Ale też wspólnoty w ogóle. Prace wielu artystów uwidzialniły wewnętrzne słabości romskiego ruchu politycznego, $\mathrm{w}$ tym te związane $\mathrm{z}$ budowaniem tożsamości na figurze ofiary. Dowiodły, że totalizująca i homogenizująca tożsamość obronna okazała się wykluczająca dla wielu romskich osób.

W tym sensie to właśnie romscy artyści z współczesną sztuką romską zrobili krok do przodu, wyprzedzając zarówno narracje polityczne, jak i kategorie większościowego świata sztuki. I choć trudno dziś przesądzać, czy postromskie strategie sztuki i polityki w przyszłości będą skuteczniejsze w czynieniu Romów widzialnymi i w propagowaniu wiedzy o Zagładzie Romów, to z pewnością budzą taką nadzieję.

31 I.M. Young, Ideał wspólnoty i polityka różnicy, przeł. A. Kowalczyk, „Praktyka Teoretyczna” 2010, nr 1, s. 41.

32 P. Gilroy, Czarny Atlantyk jako kontrkultura nowoczesności, przeł. K. Przyłuska, „Konteksty” 2012, nr 1-2, s. 19. Por. D. Baker, The queer Gypsy, „Nothing About Us Without Us? Roma Participation in Policy Making and Knowledge Production” 2015, nr 2, s. 90. 


\section{Art by visual artists of Romani origin: From difference to equality}

\section{Abstract}

The text provides an insight into subject matters taken up by Roma artists whose works address the Roma Genocide and hence are defined by its invisibility issues, trying to restore visibility to places of memory, to images of victims, to the racial motivation behind Nazi crimes against Romani people. It was my intention to retrace how, when, and whether at all these strategies have affected the (in)visibility of the Roma Genocide in majority nations. I suggest that there are two major events that define the spectrum of changes contemporary Roma art has recently undergone: the Roma Pavilion Paradise Lost at the 2007 Venice Biennale, and the First Roma Biennale staged in Berlin in 2018. It is within this framework that I analyze the relations between narratives promoted by the Roma political movement in the period of ethnic mobilization and artistic statements made by Roma artists. I have attempted to answer the question as to why the strategies of exposing the Roma Genocide to view have so far proved futile. I have also scrutinized the latest occurrences in contemporary Roma art as current endeavors to break the deadlock. One of them is "post-Romani-ness" involving attempts at redefining Roma identity and placing the Roma Genocide in a broader perspective.

Keywords: Romani people, pariah, Roma contemporary art, post-Roma art

\section{Bibliografia}

Albert Kennedy Trust, Mikey Walsh tells AKT about his coming out experiences, https://www.youtube.com/watch?v=gvwtJjGrIus (dostęp: 16.10.2017).

Baar van H, Decolonizing Canonical Roma Representations: The Cartographer with an Army, https:// www.gypsydada.com/wp-content/uploads/2018/12/Huub-van-Baar-2018-The-Cartographerwith-an-Army.pdf (dostęp: 3.12.2018).

Baker D., The queer Gypsy, „Nothing About Us Without Us? Roma Participation in Policy Making and Knowledge Production" 2015, nr 2.

Baker D., W sprawie prowizorki: kilka uwag o estetyce Romów, przeł. I. Suchan, [w:] Romano kher. O romskiej sztuce, tradycji i doświadczeniu, red. M. Weychert Waluszko, Warszawa 2013.

Barsony J., Daróczi A., Pharrajimos: The Fate of the Roma During the Holocaust, Amsterdam-New York-Brussels 2008.

Bartlová A., Jak smiŕit tradici a budoucnost?, „Artalk”, https://artalk.cz/2018/02/22/jak-smirit-tradici-a-budoucnost/?fbclid=IwAR3p1Y72bM19PDn9h7XKsUgI00QyCtihvfcjtp40c7C-m402Bf-PJ69MUNM (dostęp: 8.08.2018).

Bas Le D., Junghaus T., Europe’s Roma Struggle to Reclaim Their Arts Scene, OSI, https://www.opensocietyfoundations.org/voices/europe-s-roma-struggle-reclaim-their-arts-scene (dostęp: 13.07.2017).

Bednarek J., Queer jako krytyka spoteczna, Biblioteka Online Think Tanku Feministycznego 2014, http://www.ekologiasztuka.pl/pdf/f0132_bednarek_queer_krytyka_spoleczna.pdf(dostęp: 6.08.2019).

Benhabib S., Prawa Innych. Przybysze, rezydenci i obywatele, przeł. M. Filipczuk, Warszawa 2015.

Benhabib S., Situating the Self: Gender, Community, and Postmodernism in Contemporary Ethics, Sydney-London 1992.

Black to the future: Interviews with Samuel R. Delany, Greg Tate, and Tricia Rose, [w:] Flame Wars: The Discourse Of Cyberculture, red. M. Dery, Durham 1994. 
Blasco Gay y P., Gypsy/Roma diasporas. A comparative perspective, „Social Anthropology” 10, 2002, nr 2.

Browne S., Dark Matters. On the Surveillance of Blackness, Durham 2015.

Brzostek D., Black Science - Black Magic. Czy afrofuturyzm jest narracja poznawcza?, http:// www.journal.doc.art.pl/pdf14/artbasedresearch_brzostek_art_and_documentation14.pdf (dostęp: 10.09.2019).

Castells M., Siła tożsamości, przeł. S. Szymański, Warszawa 2008.

Chakravorty Spivak G., Czy podporządkowani inni moga przemówić?, przeł. E.A. Majewska, „Krytyka Polityczna" 2011, nr 24-25.

Chakravorty Spivak G., Krytyka postkolonialnego rozumu. W stronę historii zanikającej współczesności, [w:] Teorie literatury XX wieku. Antologia, red. A. Burzyńska, M.P. Markowski, Kraków 2006.

Chakravorty Spivak G., Milevska S., Barlow T.E., Conversations with Gayatri Chakravorty Spivak, Kalkuta 2006.

Come out now! 1st Roma Biennale. Stage Roma Armee, http:/www.roma-biennale.eu/en/1-roma-biennale/ performances/roma-armee (dostęp: 3.02.2019).

Corradi L., Gypsy Feminism: Intersectional Politics, Alliances, Gender and Queer Activism, New York 2017.

Dagbovie-Mullins S., Crossing B(l)ack: Mixed-Race Identity in Modern American Fiction and Culture, Knoxville 2013.

Damian Le Bas’ Gypsyland, red. D. Le Bas, Berlin 2018.

Eagleton T., Po co nam kultura?, przeł. A. Górny, Warszawa 2012.

Ekpo D., Poza ostatnie widma murzyńskości: postafrykanizując Senghora, Dakar i Dak'art, przeł. M. Wawrzyńczak, „Obieg”, http://obieg.u-jazdowski.pl/numery/dakar/slaying-negritude-s-las. (dostęp: 16.04.2018).

Gilroy P., Czarny Atlantyk jako kontrkultura nowoczesności, przeł. K. Przyłuska, „Konteksty” 2012, nr 1-2.

Hancock I., Downplaying the Porrajmos: The Trend to Minimize the Romani Holocaust. A review of Guenther Lewy, The Nazi Persecution of the Gypsies, New York-Oxford 2000, http://www. oocities.org/ patrin/lewy.htm (dostęp: 2.10.2017).

Hancock I., Responses to the Porrajmos (the Romani Holocaust), [w:] Is the Holocaust Unique?, red. A. Rosenbaum, Boulder 1995, http://radoc.net/radoc.php?doc=art_e_holocaust_responses\&lang=en\&articles $=$ true (dostęp: 2.10.2017).

Hancock I.F., The roots of antigypsyism: To the Holocaust and after, [w:] Confronting the Holocaust: A Mandate for the 21st Century, red. G.J. Clij, M. Sachs Littel, Lanham 1997.

Heljic A., The Revolution is Here and Now. The Revolution is Roma, Queer, and Feminist, HowlRound, https://howlround.com/revolution-here-and-now (dostęp: 8.08.2019).

Independent Theater Hungary, Mihaela Dragan, https://www.youtube.com/watch?v=6XXa5-rRgGk (dostęp: 20.09.2019).

Interview mit Sandra Selimovic (Roma Armee im Volkstheater), https://www.youtube.com/ watch?v=pAaJvaxIISQ (dostęp: 6.08.2019).

Interview with "Roma Armee" star Riah Knight, https://www.youtube.com/watch?v=HBoCx2pyt0w (dostęp: 20.09.2019).

Jay M., Refractions of Violence, New York 2003.

Jones A., Body Art / Performing the Subject, Minneapolis 1998.

Junghaus T., Globalni nomadzi, wędrowni mieszańcy $i$ wiara wspótczesnego wyrzutka, [w:] Tajsa, red. K. Roj, J. Synowiec, Tarnów 2014.

Junghaus T., Obraz i podobieństwo. Rozważania o Romach w sztuce i sztuce Romów, przeł. M. Kołaczek, „Dialog-Pheniben” 2013, nr 12. 
Junghaus T., Opór nie wystarczy. Rola romskiej sztuki we współczesnym układzie sit, przeł. M. Kołaczek, „Dialog-Pheniben” 2015, nr 17.

Junghaus T., Romska sztuka współczesna - rewolta podporządkowanych, przeł. I. Suchan, [w:] Romano kher. O romskiej sztuce, tradycji i doświadczeniu, red. M. Weychert Waluszko, Warszawa 2013.

Junghaus T., The "unpredictable" European outcast, [w:] Utopia of Alliances: Conditions of Impossibilities and the Vocabulary of Decoloniality, red. C. Agredo, S. Avraham, A. Cannito, M. Gerothanasis, M. Gržinić, M. Lôbo, I. Marjanović, Wien 2013.

Kapralski S., Naród z popiołów. Pamięć zagłady a tożsamość Romów, Warszawa 2012.

Kapralski S., Pamięć o zagładzie Romów, [w:] Romowie, red. B. Machul-Telus, Warszawa 2019.

Kapralski S., Kołaczek M., Talewicz-Kwiatkowska J., Kierunek: przyszłość. 25 lat wolności a Romowie, Kraków 2015.

Kóczé A., Trehan N., Racism, (neo)colonialism and social justice: The struggle for the soul of the Romani movement in post-socialist Europe, [w:] Racism, Postcolonialism, Europe, red. G. Huggan, I. Law, Liverpool 2009.

Krokowski H., Die Last der Vergangenheit. Auswirkungen nationalsozialistischer Verfolgung auf deutsche Sinti, Frankfurt am Main 2001.

Księżyk R., Afrofuturystki: różnica i przemiana, „Pismo” 5.06.2018, https://magazynpismo.pl/afrofuturystki-roznica-i-przemiana/\# (dostęp: 9.09.2019).

Liedtke U., Peterson P., Zur Entschädigung zwangssterilisierter Zigeuner. Sozialpsychologische Einflüsse auf psychische Störungen nationalsozialistisch Verfolgter, „Nervenartzt” 1971, nr 4.

Lindy: the Return of Little Light [film], reż. I. Persson Lännerberg, Sweden 2019.

Mbembe A., Polityka wrogości. Nekropolityka, przeł. U. Kropiwiec, K. Bojarska, Kraków 2018.

Mihaela Dragan: A weird Roma feminist, https://www.youtube.com/watch?v=s768_1jvuUg (dostęp: 20.09.2019).

Pabijanek K., From Gypsyland with love, „Critical Romani Studies” 2018, nr 1.

Repeat order, [hasło w:] Cambridge English Dictionary, https://dictionary.cambridge.org/pl/dictionary/english/repeat-order (dostęp: 9.09.2019).

Roma Artists Telling Stories of Resistance, Not Victimhood, rozmowa Mihaeli Drãgan z Sandrą Selimović, HowlRound, https://howlround.com/roma-artists-telling-stories-resistance-not-victimhood (dostęp: 8.12.2018)

Roma LGBT People Talk About the Challenges of Facing Double Discrimination, Vice, https:// www.vice.com/en_nz/article/yw3zpg/roma-lgbt-people-talk-about-the-challenges-of-facingdouble-discrimination (dostęp: 6.02.2017).

Romane Thana. Orte der Roma und Sinti [katalog wystawy], Wien 2015.

Szymański W., Od cyganerii do sztuki post-romskiej i z powrotem, „Studia Romologica” 2016, nr 9. Tumbas J., Countering persecution, misconceptions, and nationalism: Roma identity and contemporary activist art, [w:] Shifting Corporealities in Contemporary Performance Danger, Im/mobility and Politics, red. M. Gržinić, A. Stojnić, New York 2018.

Uberman I., Gorki, „Dialog” 2018, nr 7-8.

Walsh M., Cygański chtopiec. Bytem obcy wśród swoich, przeł. T. Tomczyńska, Warszawa 2011.

We Roma: A Critical Reader in Contemporary Art, red. D. Baker, M. Hlavajova, Utrecht 2013.

Weychert Waluszko M., Kiedy Johann Trollmann była mała dziewczynka, czyli pierwsze romskie biennale, „Studia Romologica” 2018, nr 11.

Weychert Waluszko M., Pokłady nierozładowanego napięcia - rozmowa z Danielem Bakerem, „Notes.na.6.tygodni” 2013, nr 88.

Young I.M., Ideał wspólnoty i polityka różnicy, przeł. A. Kowalczyk, „Praktyka Teoretyczna” 2010, $\mathrm{nr} 1$.

Prace Kulturoznawcze 24, nr 2, 2020

(C) for this edition by CNS 


$$
* * *
$$

Monika Weychert — absolwentka filologii polskiej na Uniwersytecie Mikołaja Kopernika w Toruniu, zarządzania jednostkami kultury oraz kulturoznawstwa na Uniwersytecie Adama Mickiewicza w Poznaniu, a także Podyplomowych Studiów Kuratorskich na Uniwersytecie Jagiellońskim w Krakowie. Doktoryzowała się na podstawie pracy Niewidzialna zagłada. Romska sztuka wspótczesna jako bunt podporządkowanych innych w 2020 roku (SWPS Uniwersytet Humanistycznospołeczny w Warszawie). Od 2016 roku współpracuje z Instytutem Badań Przestrzeni Publicznej ASP w Warszawie.

W Toruniu prowadziła między innymi niezależną ,galerię dla...” (2000-2008), była związana z warszawską Galerią Foksal i Muzeum Rzeźby im. Xawerego Dunikowskiego w Królikarni Oddziałem Muzeum Narodowego w Warszawie. Kuratorka kilkudziesięciu wystaw, między innymi „Patriotyzm jutra” (Instytut Sztuki Wyspa, Gdańsk 2006), „Lucim żyje!” (CSW Znaki Czasu, Toruń 2009), „Domy srebrne jak namioty” (Zachęta - Narodowa Galeria Sztuki, Warszawa 2013/ Muzeum Współczesne Wrocław 2014), „Wiosna (lato, jesień, zima) Ludów” (BWA, Tarnów 2019). Dyrektorka jedynego w Polsce cyklicznego festiwalu sztuki internetu Wyobraźnia Ekranu (20032005). Wieloletnia współpracownica TVP Kultura, autorka artykułów publikowanych w kilkunastu pismach naukowych i krytycznych, a także katalogach wystaw, redaktorka książek — członkini AICA.

weychert@gmail.com 